Tranhsfer

\section{CITPATH: Diagnostic and Hypertext Software for Fungal Diseases of Citrus Foliage and Fruit}

\author{
James J. Ferguson ${ }^{1}$, Fedro S. Zaueta ${ }^{2}$, and \\ Juan I. Valiente ${ }^{3}$
}

Additional index words. computer, extension, fruit crops

Summary. CITPATH, a computerized diagnostic key and information system, was developed to identify the major fungal diseases of citrus foliage and fruit in Florida. This software provides hypertext-linked descriptions and graphic displays of symptoms, maps of geographic occurrence, diagrams of disease development, and management strategies, with reference to chemical control methods detailed in the current Florida Citrus Pest Management Guide. Reciprocal lists of citrus cultivars susceptible to specific diseases and diseases affecting specific cultivars are included. Developed for commercial growers, county extension programs, citrus horticulture classes, and master gardeners, this software is available for MS-DOS-based computers and on CD-ROM disks containing other citrus databases.

$\mathrm{T}$ he five major fungal diseases of citrus foliage and fruit in Florida are alternaria brown spot of mandarins (Alternaria citri Ellis \& N. Pierce), greasy spot (Mycosphaerella citri Whiteside), melanose (Diaporthe citri Wolf.), phytophthora brown rot [Phytophthora citrophthora (Sm. \& Sm )], postbloom fruit drop [Colletotrichum gloeosporioides (Penz.) Penz. \& Sacc. in Penz] and sour orange scab (Elsinoe fawcetti Bitanc. and Jenk.). The

${ }^{1}$ Horticultural Sciences Department.

${ }^{2}$ Agricultural Engineering Department,

${ }^{3}$ Graduate student, Environmental Horticulture Department, University of Florida, Gainesville.

Florida Agricultural Experiment Station Journal series no. R-04403. Project supported by the Polk County, Florida Citrus Advisory Committee. The cost of publishing this paper was defrayed in part by the payment of page charges. Under postal regulations, this paper therefore must be hereby marked advertisement solely to indicate this fact. incidence and severity of these diseases depend on many factors, including cultivar susceptibility, temperature, relative humidity, rain or leaf wetness, dead twigs within the canopy, grove history, seasonal patterns of leaf drop and rainfall, the timing and seventy of pruning, and geographical location of the grove. Effective management of these diseases requires growers to recognize symptoms and understand the dynamics of disease development.

Computer software, including simulation models and expert systems, has been developed to improve disease and pest management of other perennial fruit crops. Simulation models based on weather conditions and field estimates of inoculum potential predict incidence of fire blight of pears (Jacquart-Ramon et al., 1987) and downy mildew of grapes (Blaise and Gessler. 1992: Rosa et al.. 1993). Other programs rely on monitored meteorological data from orchards (Laurenson and Manktelow, 1992) and on monitored and forecast weather (Beresford and Spink, 1992) to predict the development of apple black spot. Large, integrated expert systems for apples contain interacting modules on disease potential, pest injury, insect threshold levels and pesticide selection, application rate, spray intervals, compatibility, and days to harvest (Haley et al., 1990; Travis et al., 1992). Other expert systems, based on symptom location in plant tissue, diagnose 120 disorders of peach and nectarine trees (Plant et al., 1989), enhance the integration of pesticides with arthropod biological control on tree crops (Messing and Croft, 1990), and integrate insect and disease management on hazelnuts ( Drapek et al., 1990). Hypertext systerns, highlighted text in computer software that can be used to retrieve documents and images, have been used in CDROM agricultural databases (Beck et al., 1994), suggested as link of horticultural inquiry learning courses to videodiscs (White et al., 1990), to describe $>600$ cultivars of peach and nectarines and their performance in the southeastern United States in a hypertext version of a U.S. Dept. of Agriculture handbook (Okie, 1993), to organize and improve access to firm labor legislation (Wooddal-Gainey et al., 1992), and to provide a guide for the principles of environmental impact assessment on an international level (Engel et al., 1994).

Although interactive software is available for calculating citrus spray mixtures (Stanley and Price, 1984), ranking the potential of organic chemicals to contaminate groundwater (Nofziger et al., 1988), scheduling irrigation (Zazueta, 1990), maintaining grove records (Muraro and Ferguson, 1983), surveying and mapping tree data (Oswalt, 1985), and estimating annual net returns and the cost of tree mortality in Florida (Muraro et al., 1987), no computerized models or expert, diagnostic, or detailed hypertext systems have been published for the major fungal diseases of citrus foliage and fruit in Florida. This paper describes instructional software developed to identify symptoms and explain the dynamics of the major fungal diseases of citrus in Florida as an aid for commercial growers, county extension programs, citrus horticulture classes, and master gardeners.

\section{Program development}

The diagnostic key was generated using the Txpert Prolog code generator, version 1.0 (Zazueta, 1992). The resulting code was modified to meet the requirements of the project, compiled, and linked using Borland Turbo Prolog, version 2.0 (Borland International, 1986). The hypertext system driver was provided by the Florida Agricultural 
Information Retrieval System (FAIRS) project at the Univ. of Florida (Beck et al., 1994).

This software was evaluated by citrus extension horticulturists and pathologists, county agents with citrus responsibility, citrus production managers, and students in citrus horticulture classes. In testing the diagnostic system, distinctive, easily recognizable disease symptoms were described or diseased samples were presented and the system was used to identify the disease. The hypertext knowledge system was also reviewed by the above groups. In all cases, evaluators identified disease symptoms and retrieved information from the hypertext knowledge base quickly.

\section{Program description}

The menu lists disease submenus that can be selected with a mouse cursor or arrow keys. The help submenu provides information on windows, scrolling, menus, and hypertext that can be inspected using the arrow and enter keys. Windows conveniently displays different kinds of information simultaneously by using hide, move, and close functions available at the top of each window. A scroll bar can be used to move up and down within a window and indicate relative position within a document. Hypertext displays text so that related information can be accessed by selecting highlighted words with the mouse cursor or arrow keys to retrieve images of disease symptoms, pathogen life cycles, or information on management practices.

The introduction briefly describes factors affecting inoculum production and disease development and the two major components of CITPATH: the disease diagnosis and hypertext sections. The diagnostic key poses questions about distinctive visual disease symptoms, requiring a yes or no answer. After the disease is identified, additional symptoms not included in the key are described, along with suggested reference to the hypertext program for further information. Five major diseases of citrus foliage and fruit in Florida are included in the hypertext program. Within each hypertext section, slides of symptoms on leaves, fruit, twigs, and whole trees and Florida maps illustrating regional disease occurrence, seasonal disease development, and pathogen life cycles can be recalled. Information on disease significance, environmental and horticultural factors affecting disease development, and management strategies are included.

CITPATH will be sold as a software program by itself. It has been incorporated into CD-ROM software (FAIRS, DISC 9, below) and has been used as a model to develop a larger CD-ROM-based diagnostic program that will include citrus diseases, disorders, and pest problems.

\section{Requirements}

Required hardware includes an IBM-PC, compatible, or generic MS-DOS (3.0 or above) computer with an 80386 or 80486 CPU and a numerical coprocessor; a Super VGA monitor and compatible graphics display card; a mouse, and a hard drive with $2 \mathrm{MB}$ of available memory. The program will run on a computer with $560 \mathrm{~K}$ of conventional memory and $2 \mathrm{MB}$ of installed EMS memory. A 3.5-inch $(9-\mathrm{cm})$ floppy drive or CD-ROM is required. Since screens cannot be printed, no printer is required.

\section{Program availability}

This software is available from IFAS Software Support, P. O. Box 110340, Univ. of Florida, Gainesville, FL 32611-
0340. Phone (904) 3927853, fax (904) 392-3856. When ordering, please specify one of the following formats 1) CITPATH on 3.5- inch $(9-\mathrm{cm})$ disks (Florida residents: \$50; nonresidents: $\$ 60.00$ ), and 2) CD-ROM disc (FAIRS, DISC 9), containing CITPATH and other extension publications on citrus management (Florida residents: \$125; nonresidents: \$175.00).

\section{Literature Cited}

Beck, H. W., P. H. Jones, and D.G. Watson. 1994. A CD-ROM based agricultural information retrieval system. Applied Eng. Agr. 10: 127-1 32.

Beresford, R.M. and M. Spink. 1992. A national disease forecasting system for apple black spot (Venturia inaequalis) in New Zealand. Acta Hort. 313:285-292.

Blaise, P.H. and C. Gessler. 1992. Vinemild: Toward a management tool for grape downy mildew. Acta Hort. 313:257-262.

Borland International. 1986. Turbo Prolog owner's manual. version 2.0 Borland Intl., Scotts Valley, Calif.

Drapek, R.J., J.A. Calkin, and G.C. Fisher. 1990. A hazelnut pest management expert system. Acta Hort. 276:21-25.

Engel, B.A., J.P. Gurganus, M.E. Pearson, and D.W. Luecht. 1994. Environmental assessment resource guide hypersystem, p. 645-652. In: Watson, D. G., F. S. Zazueta and T. V. Harrison. 1994. Proc. 5th Intl. Conf. Computers in Agr. Amer. Soc. of Agr. Eng., St. Joseph, Mich.

Haley, S., K.G. Currans, and B.A. Croft. 1990. A computer aid for decisionmaking in apple pest management. Acta Hort. 276:27-34.

Jacquart-Ramon, C., D. Payen, and J.P. Paulin. 1987. A computer program based on Billing's system 1 for timing of control measures against fire blight. Acta Hort. 217: 119-123.

Laurenson, M.R. and D. W. Manktelow. 1992. Monitor: A computer-based tool for monitoring apple black spot infection periods. Acta Hort. 313:197-204.

Messing, R.H. and B.A. Croft. 1990. NERISK an expert system to enhance the integration of pesticides with arthropod biological control. Acta Hort. 276:15-19.

Muraro, R.P. and F. Ferguson. 1983. How to use the IFAS grove records system. Univ. Florida Coop. Ext. Serv., Gainesville. Circ. 567.

Muraro, R, P., F. Ferguson, G. McFerren, and P. Chunkasut. 1987. Decision aids for cirrus growers. Univ. Florida Coop, Ext. Serv., Gainesville. Circ. 689

Nofziger, D.L., P.S. Rae, and A.G. Hornsby. 1988. CHEMRANK. Interactive software for ranking the potential of organic chemicals to contaminate groundwater. Univ. Florida Coop. Ext. Serv., Gainesville. Circ. 788

Okie, W.R. 1993. Peach and nectarine varieties-A hypertext index. HortScience 28:1186-1187.

Oswalt, T.W. 1985. Citrus survey and mapping microcomputer programs. Univ. Florida Coop. Ext. Serv., Gainesville. Circ. 660.

Plant, R. E., F.G. Salem, J.A. Young, and R.E. Rice. 1989. CALEX/Peaches, an expert system for the diagnosis of peach and nectarine disorders. Hortscience $24: 700$.

Rosa, M., R. Genetio, B. Gozzini, G. Maracchi, and S. Orlandini. 1993. PLASMO: A computer program for grapevine downy mildew development forecasting. Computers Electronics Agr. 9:205-215.

Stanley, C.D. and J.F. Price. 1984. A microcomputer program for performing pesticidal spray calculations. Univ. Florida Coop. Ext. Serv., Gainesville. Circ. 612.

Travis, J. W., E. Rajotte, R. Bankert, K. D. Hickey, L. A. Hull, V. Eby, P. H. Heinemann, R. Crassweller, and J. McClure, 1992. Penn State apple orchard consultant: design and function of the pest management module. Acta Hort. 313:209-213.

White, J. W., D.J. Beatie, and P. Kubek. 1990. Inquiry learning with videodiscs and computers: An innovative teaching method for horticulture courses. Hortscience 25:385-388.

Wooddall-Gainey, D., J. Alevany, and P.W. Lanier. 1992. Development of a hypertext computer program to promote compliance with farm labor laws. Computers Electronics Agr, 7:109-120.

Zazueta, F.S. 1990. Citrus irrigation scheduling. Univ. Florida Coop. Ext. Serv., Gainesville. Circ. 332.

Zazzeta, F.S. 1992. Rapid protyping of expert systems. version 1.0. Proc. Intl. Conf. Computers in Agr. Univ. of Florida, Gainesville. 